\title{
Short-Termism and Capital Flows
}

\section{Citation}

Fried, Jesse M., and Charles C.Y. Wang. "Short-Termism and Capital Flows." Review of Corporate Finance Studies 8, no. 1 (March 2019): 207-233. (Was Harvard Business School Working Paper, No. 17-062, January 2017; Revised November 2018.)

\section{Published Version}

https://doi.org/10.1093/rcfs/cfy011

\section{Permanent link}

http://nrs.harvard.edu/urn-3:HUL.InstRepos:30000680

\section{Terms of Use}

This article was downloaded from Harvard University's DASH repository, and is made available under the terms and conditions applicable to Open Access Policy Articles, as set forth at http:// nrs.harvard.edu/urn-3:HUL.InstRepos:dash.current.terms-of-use\#OAP

\section{Share Your Story}

The Harvard community has made this article openly available.

Please share how this access benefits you. Submit a story.

Accessibility 


$$
\text { H A R VAR D B US INESS S C HOOL }
$$

\section{Short-Termism and Capital Flows}

Jesse M. Fried

Charles C.Y. Wang

Working Paper 17-062 


\title{
Short-Termism and Capital Flows
}

\author{
Jesse M. Fried
}

Harvard Law School

Charles C.Y. Wang

Harvard Business School

Working Paper 17-062 


\title{
Short-Termism and Capital Flows
}

\author{
Jesse M. Fried \\ Harvard Law School \\ Charles C.Y. Wang* \\ Harvard Business School \\ Forthcoming, Review of Corporate Finance Studies
}

November 2018

\begin{abstract}
During 2007-2016, S\&P 500 firms distributed to shareholders $\$ 7$ trillion via buybacks and dividends, over $96 \%$ of their aggregate net income, prompting claims that "shorttermism" is impairing firms' ability to invest and innovate. We show that, when taking into account both direct and indirect equity issuances, net shareholder payouts by all public firms during this period were only $41 \%$ of net income. And, in fact, during this decade investment increased substantially while cash balances ballooned. In short, S\&P 500 shareholder-payout figures cannot provide much basis for the notion that short-termism has been depriving public firms of needed capital.
\end{abstract}

Keywords: short-termism; quarterly capitalism; corporate governance; share buybacks; open market repurchases; dividends; equity issuances; seasoned equity offerings; equity compensation; acquisitions; payout policy; capital flows; capital distribution

JEL: G14, G32, K22

*Fried (jfried@law.harvard.edu) is the Dane Professor of Law at Harvard Law School. Wang (charles.cy.wang@hbs.edu) is the Glenn and Mary Jane Creamer Associate Professor of Business Administration at Harvard Business School. We thank the Editor Andrew Ellul and an anonymous referee for their guidance. We are also very grateful to Justin Kenney and especially Kyle Thomas for research assistance, and to Jordan Barry, Lucian Bebchuk, Martijn Cremers, Elisabeth de Fontenay, Stephen Giove, Paul Healy, Colleen Honigsberg, Marcel Kahan, Louis Kaplow, Trevor Norwitz, Charles O’Kelley, Lynn Paine, Frank Partnoy, Charlie Penner, Mark Roe, James Spindler, Jennifer Taub, Anne Tucker, Yesha Yadav and participants at conferences and seminars at Georgia State University College of Law, Harvard Law School, Harvard Business School, Hebrew University, Notre Dame Law School, Tel Aviv University, and the University of Pennsylvania Law School for helpful comments and conversations. A prior version of this paper was circulated under the title "Short-Termism and Shareholder Payouts: Getting Corporate Capital Flows Right." All errors are our own. 
The effects of the short-termist phenomenon are troubling... more and more corporate leaders have responded with actions that can deliver immediate returns to shareholders, such as buy-backs or dividend increases, while underinvesting in innovation, skilled workforces or essential capital expenditures necessary to sustain long-term growth. In 2014, dividends and buybacks... [in S\&P 500 firms] alone totaled more than $\$ 900$ billion... the highest level on record.

Larry Fink, Chair and CEO of BlackRock, April 15, 2015

\section{Introduction}

A fierce debate has been raging over whether shareholder-driven "short-termism" (or "quarterly capitalism") - that managers give up profitable long-term investments to increase the short-term stock price - is a critical problem for U.S. public firms, their investors, and the nation's economy. Quarterly capitalism, exacerbated by the growing power of hedge funds, is claimed to substantially impair firms' ability to invest and innovate for the long term (Coffee and Palia, 2015; Strine, 2010; Aspen Institute, 2009). Others disagree, arguing that hedge funds play a useful role in the market ecosystem (Bebchuk and Jackson, 2012; Gilson and Gordon, 2013; Kahan and Rock, 2007) and that concerns over short-termism are greatly exaggerated (Bebchuk, 2013; Roe, 2013; Kaplan, 2017; Roe, 2018).

As short-termism can arise even in a rational market (Stein, 1989), there is likely some short-termist behavior by managers of public firms. Indeed, there is evidence suggesting that market pressures can lead managers to take actions that are designed to boost the short-term stock price but come at the expense of long-term value (Bushee, 1998; Dichev, Graham, Harvey, and Rajgopal, 2013; Graham, Harvey, and Rajgopal, 2006), and that such pressures may undesirably reduce investment at public firms (Asker, Farre-Mensa, and Ljungqvist, 2015).

\footnotetext{
${ }^{1}$ Fink, Larry. "Annual Letter to CEOs." April 15, 2015.
} 
However, the policy question is whether shareholder-driven short-termism is so damaging that investors' power should be curtailed, a move that would increase managerial agency costs. There is not yet consensus on the answer (Bebchuk, Brav, and Jiang, 2015; Cremers, Giambona, Sepe, and Wang, 2016; Cremers, Litov, and Sepe, 2017).

Recently, attention has turned to the increasing volume of repurchases. Both buybacks and dividends can mitigate agency costs (Easterbrook, 1984; Jensen, 1986) and buybacks are generally welcomed by investors (Grullon and Michaely, 2004). But repurchases can be inappropriately driven by short-term incentives to meet EPS targets (Hribar, Jenkins, and Johnson, 2006) or by pressures from activist hedge funds (Farre-Mensa, Michaely, and Schmalz, 2018), potentially reducing investment for long-term growth (Almeida, Fos, and Kronlund, 2016). Thus, the increased amount of buybacks can be seen as consistent with short-termism (e.g., Gutiérrez and Philippon, 2017).

One prominent claim is that the high volume of repurchases is leading firms to distribute too much of their net income to shareholders, potentially limiting their ability to invest and innovate (Lazonick, 2014). In fact, Lazonick (2014) shows that during 2003-2012 S\&P 500 firms spent $91 \%$ of their aggregate net income (a total of $\$ 2.4$ trillion) on buybacks (54\% of net income) and dividends (37\% of net income). The high ratio of shareholder payouts to net income has been cited by other economists (Kahle and Stulz, 2017) as evidence that U.S. public firms have limited opportunities or incentive to invest, and by asset managers (Fink, 2015), leading corporate lawyers (Lipton, 2015), and senior politicians (Biden, 2016) as evidence that market pressures deprive firms of the capital needed for long-term investment. Senator Elizabeth Warren cited such payout-ratio figures as justification for her recentlyintroduced Accountable Capitalism Act (Office of Elizabeth Warren, 2018).

In this paper, we analyze whether these shareholder-payout figures can provide evidence 
that short-termism is a serious problem. The answer, in short, is no. We argue that S\&P 500 shareholder payouts provide an incomplete and distorted picture of corporate capital flows and their impact on firms' investment capacities; when properly measured, net capital outflows from public firms to their shareholders are much smaller than they seem, and thus appear unlikely to substantially impair these firms' long-term investment capacity. Our argument proceeds in three steps.

First, we show that one cannot measure capital movements between firms and their shareholders without properly accounting for equity issuances by firms. Clearly, shareholder payouts (dividends plus repurchases) tell only half the story; what matters is net shareholder payouts: dividends plus repurchases, minus equity issuances. The need to take into account equity issuances is not new; a number of papers have sought to take into account issuances, using various approaches, to calculate either net payouts to shareholders by public firms or net equity issuances (issuances minus repurchases) (e.g., Fama and French, 2001, 2005; Skinner, 2008; Floyd, Li, and Skinner, 2015; Farre-Mensa et al., 2018). But many of these papers include in their measure of equity issuances only direct issuances (i.e., issuances of shares to investors for cash), not indirect issuances (e.g., issuances of shares to employees, who later sell the shares to investors for cash). We explain why it is crucial to include both direct and indirect equity issuances, and show that indirect issuances are significant. For example, during 2007-2016 public firms issued approximately $\$ 2.3$ trillion of shares for equitybased compensation, while direct equity issuances were only around $\$ 1.6$ trillion. Excluding indirect issuances will thus lead to a substantial overestimation of capital flows from firms to shareholders.

Second, we show that accounting for direct and indirect equity capital inflows drives a massive wedge between shareholder-payout figures (which are cited as evidence of short- 
termism) and net shareholder payouts (that measure actual capital movement between firms and shareholders). During 2007-2016, S\&P 500 firms distributed to shareholders more than $\$ 4.2$ trillion through stock buybacks and about $\$ 2.8$ trillion through dividends. These cash outflows, totalling $\$ 7$ trillion, represented $96 \%$ of these firms' net income during that decade. But during this same period, S\&P 500 firms absorbed, directly or indirectly, $\$ 3.3$ trillion of equity capital from shareholders through share issuances. Net shareholder payouts from S\&P 500 firms were therefore only about $\$ 3.7$ trillion, or $50 \%$ of these firms' net income.

Third, we demonstrate that a focus on S\&P 500 firms - which generally have fewer growth opportunities than smaller and younger firms - creates a misleading picture of net shareholder payouts in the public markets as a whole. We show that while S\&P 500 firms are net exporters of equity capital, public firms outside of the S\&P 500 are net importers. During 2007-2016, they absorbed $\$ 406.8$ billion of equity capital, or about $11 \%$ of the net shareholder payouts of S\&P 500 companies. Across all public firms, net shareholder payouts during 2007-2016 were only $\$ 3.3$ trillion, about $41 \%$ of these firms' net income over this period.

After showing that net shareholder payouts are substantially lower than shareholder payouts, and thus a much more modest fraction of firms' net income, we present additional data relating to firms' ability to invest and innovate. We calculate that U.S. public firms, even after making $\$ 3.3$ trillion in net shareholder payouts during 2007-2016, generated during this period about $\$ 6.6$ trillion of cumulative income that was potentially available for $R \& D$ and other investment. Further, we show that public firms deployed much of this capacity for investment in R\&D and CAPEX. In absolute terms, total investment (R\&D and CAPEX) rose to a record level. And relative to revenues, total investment rose to levels not seen since the late 1990s economic boom. Nor do these expenditures appear constrained by cash availability, as cash balances ballooned from $\$ 3.3$ to $\$ 4.9$ trillion during the decade. 
Finally, looking beyond the public-firm data, we make two observations about why net shareholder payouts by public firms are unlikely to pose a problem for the U.S. economy. First, these firms' investment capacity is essentially unlimited because a public firm that needs more equity capital can simply issue more shares, as long as the firms secures any needed shareholder approval. Second, net shareholder payouts are not necessarily "wasted" from an economy-wide investment or innovation perspective; they can be recycled to provide capital for private firms, which actually employ most of the nation's workforce and are responsible for a considerable amount of innovation and dynamism in our economy.

To be sure, our analysis does not address whether pressures from shareholders or activist investors are causing some public firms to distribute too much cash to shareholders (or are generating other costs unrelated to capital flows). However, a close look at the data reveals that there is little reason to believe - based on public-firm shareholder payouts - that shorttermism is, as many claim, systematically stripping public firms of the capital needed to invest and innovate, or causing harm to our economy as a whole.

Our work contributes to the academic and public debates over the magnitude of shorttermism and its potential effects on on public firms' investment capacity. The evidence and analysis we put forward suggests there is little empirical support for the claim that shorttermism is causing public firms to distribute so much cash to investors that they are "eating themselves" and lack the resources for long-term investment.

We also contribute to the large literature on corporate payouts. Closest to our work in terms of topic is Farre-Mensa et al. (2018), which examines how the cash for shareholder payouts by individual public firms is obtained by those firms. They find that a significant portion of these payouts are financed by firms issuing additional equity and debt. Because their interest is in tracking flows of cash directly into and out of particular firms, they 
focus only on direct (cash-raising) issuances, ignoring indirect issuances. Our interest, by contrast, is in net payouts to public investors, which requires a calculation of both direct and indirect issuances. We show that the magnitude of indirect equity issuances is substantial, and (at least for our purpose) these issuances should not be ignored. Also related to our work, in terms of methodology, are Fama and French (2005) and Welch and Goyal (2008). Like us, both use the "share-count" method to measure net equity issuances. However, the topics of these papers are far different; the former tests the pecking-order hypothesis and the latter tests asset-pricing theories. Thus, these two papers do not, as we do, seek to classify the various types of issuances, measure total equity issuances, or estimate net shareholder payouts, either on a firm or market-level basis.

The remainder of this paper proceeds as follows. Section 2 describes shareholder payouts in S\&P 500 firms and the importance of taking into account direct and indirect equity issuances. Section 3 re-examines equity capital flows between shareholders and S\&P 500 firms. Section 4 analyzes net equity capital flows for all public firms. Section 5 provides data on these firms' investment capacity, investment levels, and cash balances. Section 6 explains why public firms' ability to issue additional equity, and private firms' ability to use some of the cash distributed by public firms, means that the negative effect of net shareholder payouts by public firms on investment levels in the larger economy is likely to be overstated. Section 7 concludes.

\section{Net Shareholder Payouts}

We begin by examining the dollar amount of shareholder payouts - the sum of dividends and repurchases - by S\&P 500 firms during 2007-2016. We then explain the need to take 
into account indirect (as well as direct) equity issuances to properly calculate net shareholder payouts.

\subsection{Shareholder Payouts of S\&P 500 Firms}

To compute shareholder payouts, we rely on data from the Compustat annual fundamental file. For dividends, we use dividends to common shares (Compustat variable $d v c$ ). For repurchases, we follow Boudoukh, Michaely, Richardson, and Roberts (2007), combining the dollar amounts spent to repurchase common and preferred shares (prstkc) and removing the effect of preferred shares by deducting the decrease in the redemption value of preferred shares (pstkrv). Our empirical analysis throughout the paper uses a sample of public firms at the intersection of CRSP and Compustat during 2007-2016. We include only observations with CRSP share code of 10 or 11 (i.e., the sample excludes certificates, ADRs, shares of beneficial of interest, units, companies incorporated outside the United States, Americus Trust components, closed-end funds, and REITs). We also exclude any firm entering the public market (through an IPO) or exiting the public market (through a going-private transaction, bankruptcy, or other delisting) in a given calendar year, thus excluding the equity-capital flows in the calendar year of such entrance or exit event. This allows us to circumvent the practical difficulties of tracking capital flows as firms and shareholders cross the public/private boundary. Finally, our analyses utilize S\&P 500 membership status obtained from Compustat. To be included in our S\&P 500 sample in a calendar year, a firm must be a member of the index at the fiscal-period end occurring in that calendar year.

Figure 1 shows that during 2007-2016 S\&P 500 firms distributed $\$ 7$ trillion of cash back to shareholders: $\$ 4.2$ trillion through repurchases and $\$ 2.8$ trillion through dividends. Similar to Lazonick (2014) which examines a slightly earlier period, we find that $96 \%$ of the $\$ 7.3$ trillion 


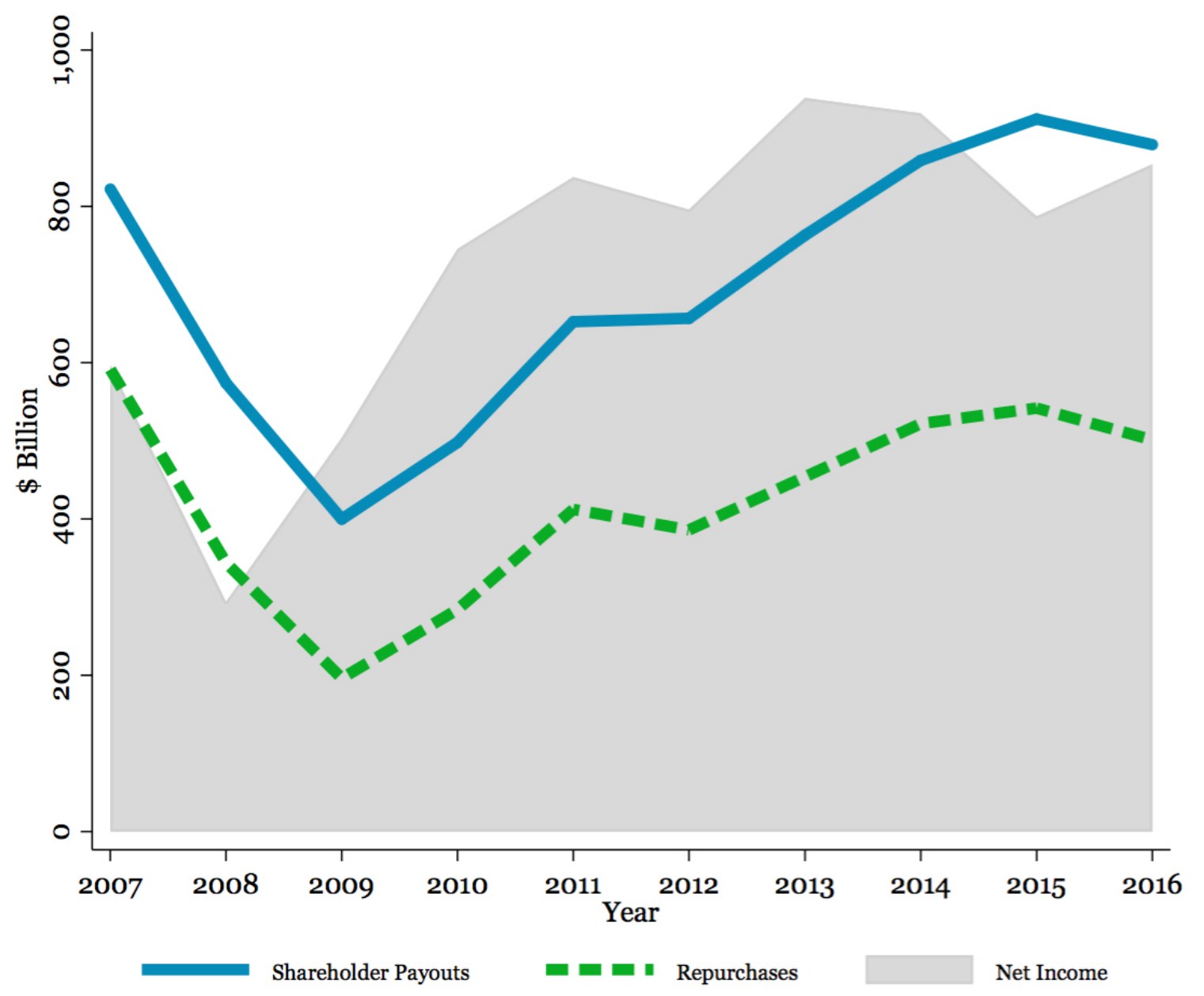

Fig. 1. S\&P 500 Shareholder Payouts (2007-2016)

The solid line depicts the time series of total shareholder payouts (dividends + repurchases) among S\&P 500 firms. The dashed line and the gray background depict the time-series of S\&P 500 aggregate repurchases and net income. Details of variable construction are presented in Table A1.

in cumulative net income generated by S\&P 500 firms during 2007-2016 was distributed to shareholders through dividends and repurchases. If there were no equity issuances, these figures might suggest that companies were "eating themselves," depriving themselves of cash needed to invest and innovate. 


\subsection{The Need to Properly Account for Equity Issuances}

Clearly, the problem with using only share repurchases and dividends to capture capital flows between firms and shareholders is that it reflects a flawed assumption: that capital moves only from firms to shareholders. In fact, firms that have conducted an initial public offering (IPO) subsequently issue common shares to investors through both direct (cashraising) equity issuances (e.g., at-the-market or seasoned equity offerings) and indirect equity issuances (e.g., grants of stock to employees, who later sell the stock to investors).

To include the effect of equity issuances, we seek to measure net shareholder payouts: dividends plus repurchases minus equity issuances or, equivalently, dividends minus net equity issuances (issuances minus repurchases). The finance literature offers three approaches to estimating net equity issuances. The first is to measure the difference between cash inflows from equity issuances and cash outflows from repurchases, using cash-flow statement data from Compustat (e.g., Frank and Goyal, 2003; Lemmon and Zender, 2003; Lee, Shin, and Stulz, 2016). The cash-flow approach excludes all indirect equity issuances. The second approach to measuring net equity issuances uses changes in treasury stock, based on balance-sheet data from Compustat (e.g., Fama and French, 2001; Skinner, 2008; Floyd et al., 2015). The treasury-stock approach includes certain indirect equity issuances, but not all. In particular, it captures only the indirect issuances of shares that had previously been repurchased, thereby excluding indirect issuances of newly issued shares. The third approach is to measure changes in share count and multiply those changes by the stock price, using data from CRSP (e.g., Fama and French, 2005; Welch and Goyal, 2008; Boudoukh et al., 2007). As noted in Fama and French (2005), the share-count method provides the most accurate measure of net equity issuances because it is the only method that accounts for all indirect equity issuances. 
Below we describe direct equity issuances and explain why, to accurately measure capital flows between firms and shareholders, one must also take into account indirect equity issuances. Indeed, a majority of equity issuances are indirect; ignoring them would thus significantly overstate net shareholder payouts.

\subsubsection{Direct Equity Issuances}

Direct (or "cash-raising") equity issuances are those for cash consideration. Examples include seasoned equity offerings, at-the-market offerings, private placements, rights offerings, dividend-reinvestment plans (DRIPs), and direct purchase plans. We estimate that, during 2007-2016, public firms (both in and outside the S\&P 500) raised about $\$ 1.6$ trillion via cash-raising issuances. ${ }^{2}$

\subsubsection{Indirect Equity Issuances}

Indirect equity issuances are those issuances for non-cash consideration. As explained below, most fall into one of two categories: issuances in connection with employee compensation ("employee-paying issuances"), and issuances in connection with acquisitions of other firms or assets ("acquisition-financing issuances"). While employee-paying and acquisitionfinancing issuances do not directly move cash from public investors to the firm, they have similar economic effects: both enable the firm to use public investors' cash to pay for needed inputs. The only difference is that a direct issuance moves investors' cash to the input provider after a potentially brief stop at the firm, while an indirect issuance to an input provider moves investors' cash straight to the input provider (when the input provider sells

\footnotetext{
${ }^{2}$ Our method for estimating equity issuances is detailed in Section 3.2. In short, we add repurchases (from Compustat) back to an estimate of net equity issuances (from CRSP). Unlike Section 3.2, here we compute estimates of total equity issuances for all public firms during 2007-2016.
} 
the issued shares to investors).

Put differently, an indirect issuance is economically equivalent to the following two-part transaction: (1) a firm sells shares for cash to public investors (a cash-raising issuance) and (2) the firm uses that cash for a particular purpose (such as paying employees or acquiring assets). ${ }^{3}$

Thus, from an economic perspective, both direct and indirect equity issuances effectively move capital from public investors to the firm for various uses, and thus both offset repurchases and dividends. The dollar value of all equity issuance must, accordingly, be taken into account in determining net shareholder payouts.

2.2.2.1 Employee-Paying Issuances The most important type of indirect issuances are those connected to employee compensation. Employees are frequently given restricted shares or stock options, both of which are typically subject to vesting requirements. When restricted stock vests, employees may sell the stock on the market. When options vest, employees can exercise the options by paying the option strike price to the firm; the stock received via exercise of the option can then be sold on the market.

While the use of restricted shares or stock options to compensate employees does not involve the direct receipt by the firm of cash equal to the value of shares issued, an employingpaying issuance is economically equivalent to a transaction in which the firm (1) engages in a simple cash-raising issuance and (2) then uses the cash raised to pay employees. Figure 2 illustrates this equivalence.

Suppose, for example, that ABC Corporation ("ABC") could sell a share for $\$ 100$ to

\footnotetext{
${ }^{3}$ In addition to employee-paying and acquisition-financing issuances, other (and much less important) types of indirect equity issuances include stock issued pursuant to the conversion of convertible debt or preferred stock. These transactions can similarly be characterized as (1) a cash-raising issuance of common stock to the convertible security holder followed by (2) a cash payment to the convertible security holder to repay or redeem the security.
} 


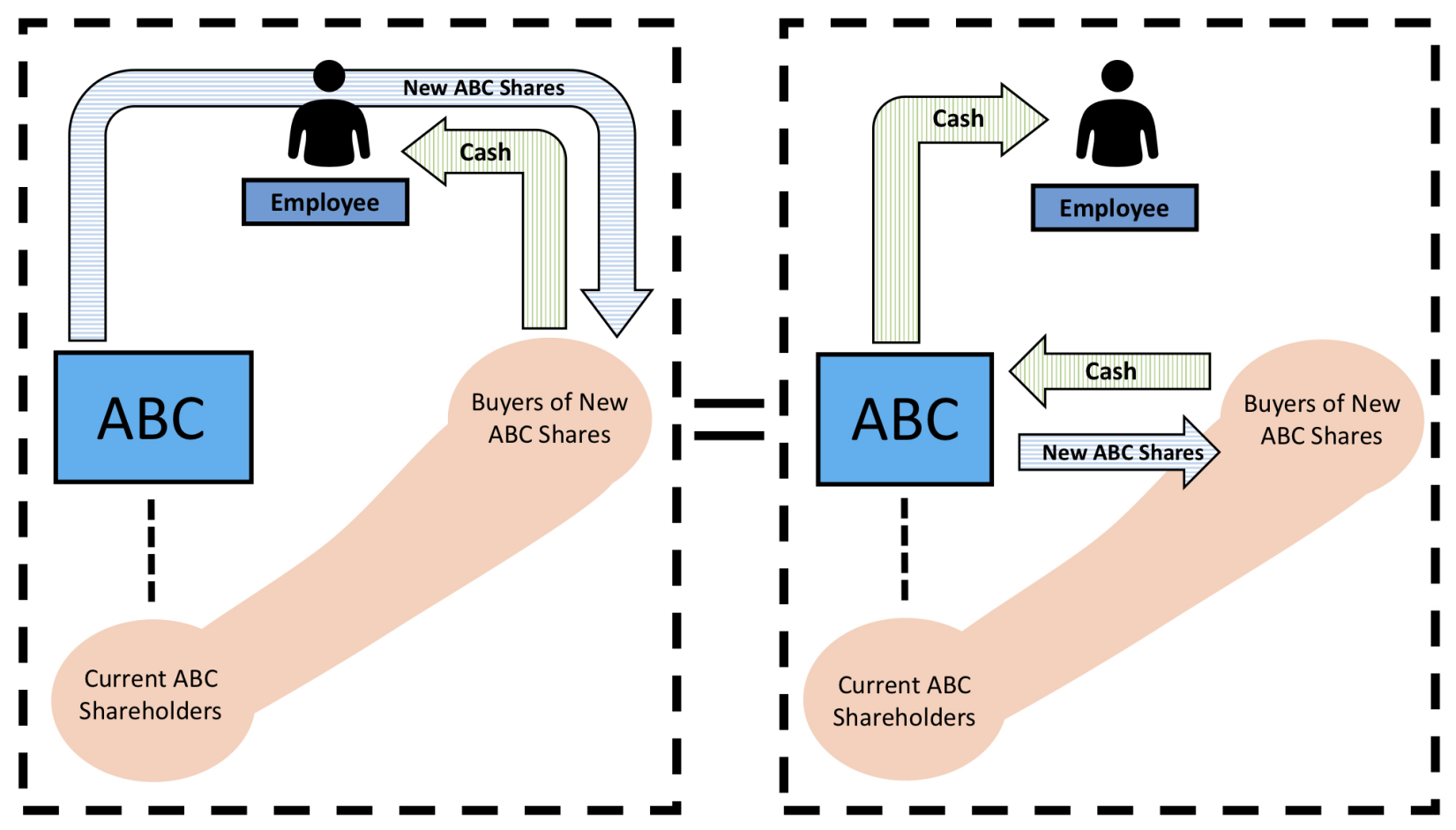

Fig. 2. Employee-Paying Issuances

The left-hand panel depicts the actual employee-paying issuance: ABC issues its own shares to Employee, who then sells the shares to public investors. In the right-hand panel, ABC conducts a cash-raising issuance, then uses the cash to pay Employee. At the end of both transactions, ABC's cash position is identical, Employee has the same amount of cash in her pocket, and public investors have acquired new $\mathrm{ABC}$ shares for cash.

public investors, and then pay $\$ 100$ to an employee ("Employee"). Or ABC could give Employee a share and permit Employee to sell the share on the market for $\$ 100$. From the perspectives of ABC, Employee, and ABC's shareholders, the outcomes of these two arrangements are identical: ABC's cash position is unaffected, Employee ends up with $\$ 100$ in her pocket, and ABC's public investors have acquired 1 new ABC share for $\$ 100$.

The equivalence would remain if $\mathrm{ABC}$ uses options rather than shares to compensate Employee. Suppose, for example, that ABC gives Employee an option with a $\$ 40$ strike price when the stock trades for $\$ 100$. Employee exercises the option by paying $\mathrm{ABC} \$ 40$, 
acquires the share, and sells the share to public investors for $\$ 100$. The result is equivalent to $\mathrm{ABC}$ (1) selling a share for $\$ 100$ to public investors, and (2) then paying $\$ 60$ to Employee and using the remaining $\$ 40$ for other purposes. In both scenarios, public investors pay $\$ 100$ to obtain a new share of $\mathrm{ABC}$, Employee gets $\$ 60$, and $\mathrm{ABC}$ gets $\$ 40$ in cash.

To ascertain the magnitude of employee-paying equity issuances, we obtained from Equilar a comprehensive dataset with detailed information on the equity compensation plans of public companies in their database during 2007-2016. Their database includes almost all public firms, and all firms belonging to the Russell 3000 index during this period: an average of 5,121 firms per year.

We compute the number of shares issued to all employees-both named executive officers (typically, the five highest-paid) and lower-level employees-through the vesting of restricted shares (or restricted stock units) and the exercise of stock options. Applying the fiscal-yearend price to these issued shares, we estimate that during 2007-2016 about $\$ 2.3$ trillion worth of equity was issued to all public-firm employees. On average, each firm issued $\$ 46$ million of equity per year for this purpose. Interestingly, we estimate that only 15\% (\$352 billion in total, or $\$ 7$ million per year per firm) went to named executive officers. The bulk, $85 \%$, went to lower-level employees.

These $\$ 2.3$ trillion in employee-paying issuances are about 1.5 times larger than the $\$ 1.6$ trillion of direct issuances. Obviously, failing to account for employee-paying issuances would lead to a substantial underestimation of total equity issuances.

The magnitude of employee-paying issuances also suggests that the common concerns that shareholder payouts leave "very little for... higher incomes for employees" (Lazonick, 2014) is misguided. In fact, one of the most important reasons firms repurchase stock is to acquire shares to pay employees (Kahle, 2002; Bens, Nagar, Skinner, and Wong, 2003). For 
such compensation-driven repurchases, the cash that flows out to public shareholders in the repurchase leg of the transaction finds its way to employees when they get the repurchased shares and sell them back to public shareholders. By focusing solely on the first leg of this transaction (the repurchase of shares from public investors), and ignoring the second leg (the sale of the repurchased shares by employees to shareholders), it would appear that cash moves from the corporation to shareholders, potentially compromising the firm's ability to pay employees higher wages. In fact, the effect of these two legs of the transaction, taken together, is to move cash from the corporation to employees. And, like any type of compensation paid by the firm, the cost of this compensation is borne indirectly by the firm's shareholders, reducing their returns.

2.2.2.2 Acquisition-Financing Issuances Public companies frequently use cash to acquire the shares (and, indirectly, the assets) of target companies, both public and private. ${ }^{4}$ However, an acquirer can use its own equity in lieu of cash for such an acquisition (Fama and French, 2005). Conceptually, an acquisition-financing issuance is economically equivalent to (1) a cash-raising issuance followed by (2) the use of that cash to acquire the stock (and, indirectly, the assets) of the target firm.

Using a sample of approximately 5,000 M\&A transactions during 1980-2008 involving a U.S.-domiciled target and a U.S.-domiciled public bidder, (Eckbo, Makaew, and Thorburn, 2016) estimates that $31 \%$ of the acquisitions were financed entirely by the issuance of acquirer stock and $40 \%$ were financed by a mix of cash and stock. We estimate, using a comprehensive sample of M\&A transactions obtained from SDC, that during 2017-2016 public bidders used approximately $\$ 930$ billion of their own equity to acquire other firms; about $80 \%$ of these acquisition-financing issuances involved the purchase of private firms. Thus, acquisition-

\footnotetext{
${ }^{4}$ In some cases, target assets are purchased directly by the acquirer from the target.
} 
financing issuances were smaller than both employee-paying issuances ( $\$ 2.3$ trillion) and direct issuances ( $\$ 1.6$ trillion), but still substantial.

\section{Total Equity Issuances and Net Shareholder Payouts by the S\&P 500}

Having explained the importance of accounting for indirect as well as direct issuances, we proceed to estimate total equity issuances and net shareholder payouts by S\&P 500 firms during 2007-2016 using the sample described in Section 2.

\subsection{Methodology}

To estimate net shareholder payouts for public firms, we compute for each firm dividends paid and net equity issuances:

$$
\text { Net Shareholder Payouts }=\text { Dividends - Net Equity Issuances }
$$

where net equity issuances is defined as the dollar amount of direct and indirect share issuances minus the dollar amount of share repurchases. We estimate both dividends and net equity issuances on a monthly basis using CRSP.

Monthly dividends paid by a firm are estimated using the available fields in the monthly stock file as follows: 
Dividends $_{t}=$ Dividend Yield $_{t} \times$ Stock Price $_{t-1} \times$ Shares Outstanding $_{t}$,

where $t$ is an index for time; dividend yield is given by the difference between a stock's monthly total return (the CRSP field ret) and a stock's return from capital gains (the CRSP field retx). To make prices and shares outstanding comparable over time, we follow standard practice in adjusting them using CRSP's cumulative adjustment factors. ${ }^{5}$ Dividend estimates obtained using this method are consistent with the numbers reported by Compustat. For example, among S\&P 500 firms during 2007-2016, average aggregate annual dividends paid is estimated as $\$ 273$ billion using CRSP and as $\$ 279$ billion using Compustat, and the two estimates are $99 \%$ correlated at the firm-year level. The advantage of the CRSP approach is that it allows us to cumulate dividends at monthly frequencies and over standardized time horizons (e.g., a calendar year) across firms. By contrast, Compustat reports information only by fiscal year, which is not uniformly defined.

To estimate net equity issuances, we follow the share-count method using available fields in both the monthly and daily stock file, in a manner similar to Fama and French (2005), Boudoukh et al. (2007), and Welch and Goyal (2008):

Net Equity Issuances $_{t}=\Delta$ Shares $_{t} \times$ Average Stock Price $_{t}$,

where $\Delta$ Shares $_{t}$ is the change in shares outstanding from the end of the prior month to the current month, and Average Stock Price $_{t}$ is the average daily stock price over the current

\footnotetext{
${ }^{5}$ Shares outstanding is computed as shrout $t_{t} \times c f a c s h r_{t}$, and lagged stock price is given by $\frac{p r c_{t-1}}{c f a c p r_{t-1}}$.
} 
month. The main difference between our implementation of the share-count methodology and others' is the assumed price at which the net equity issuance occurs. Whereas Fama and French (2005) uses the average of beginning and end-of-month prices and Welch and Goyal (2008) uses end of month prices, our approach uses the average of daily prices over the calendar month. ${ }^{6}$ Because repurchases and equity issuances take place throughout the entire month, the average daily price is likely to better reflect the price at which these transactions take place than a measure using price information from only one or two days during the month.

Nevertheless, this share-count method can still be expected to over-estimate net shareholder payouts. Repurchases generally take place at below-average prices (e.g., Simkovic, 2009) and equity issuances generally place at above-average prices (e.g., Baker and Wurgler, 2002). However, the share-count approach assumes that equity issuances and repurchases that take place within the same calendar month occur at the same prices (i.e., the average closing daily stock price), leading to an upward bias in net shareholder payouts. Accordingly, actual net shareholder payouts are likely to be even lower than the ones we report; our estimates are therefore conservative.

One other point is worth noting. Our approach, by treating all issuances identically, treats an acquisition-paying issuance by one public firm to buy the assets of another as if it were any other kind of indirect (or direct) equity issuance. In fact, such a "public-public" acquisition-paying issuance does moves capital from public investors to the acquiring firm, like any other issuance by that firm. But it does not move capital from public investors in the aggregate to public firms. Rather, it just changes the type of "tickets" public investors (in the aggregate) hold; instead of holding shares in two public companies, they now hold

\footnotetext{
${ }^{6}$ Again, to make shares outstanding comparable over time, we follow the standard practice of adjusting them using CRSP's cumulative adjustment factors.
} 
shares in (a larger) one. However, our results would not change materially if public-public acquisition-paying issuances were excluded from our calculations. For example, using M\&A transaction data obtained from SDC, we estimate that during 2007-2016 public firms used only $4 \%$ of their issuances to acquire shares of other public firms. ${ }^{7}$

\subsection{S\&P500 Total Issuances and Net Shareholder Payouts}

We first report the annual dollar volume of equity issuances by S\&P 500 firms during 2007-2016. We obtain yearly issuance volume by adding repurchases (from Compustat) to net equity issuances (estimated from CRSP via equation 3). Figure 3 shows issuance volumes for each year during 2007-2016, alongside repurchases and dividends. The dollar volume of equity issuances was in fact higher than the dollar volume of repurchases in 2009 and 2010. Over the entire decade, the total volume of equity issuances totaled about $\$ 3.35$ trillion, $21 \%$ less than the $\$ 4.2$ trillion in repurchases during the same period.

Because the dollar volume of equity issuances is so large, net shareholder payouts (at $\$ 3.67$ trillion) are much lower than shareholder payouts (\$7.02 trillion). Figure 4 shows annual shareholder payouts and net shareholder payouts in S\&P 500 firms during 2007-2016, against a backdrop of net income. Net shareholder payouts by the S\&P 500 were, each year, on average $48 \%$ of shareholder payouts, and in one year (2009) were negative: public

\footnotetext{
${ }^{7}$ A similar type of complication arises when one public acquiring company uses cash to acquire the shares of a public company, which then flows to the target's investors. Unlike a repurchase or dividend, this cash does not flow from the acquiring public firm to its own investors. But it does flow from public firms to public investors in the aggregate. Our methodology does not capture this final-period payout from the target to its investors because, in any given calendar year, we measure payouts from, and issuances by, only those firms that remain public the entire year. Again, however, our results would not be materially different if we included such payments as dividends or repurchases when calculating shareholder payouts. Using M\&A transaction data obtained from SDC, we estimate that during 2007-2016 public firms spent only $\$ 175$ billion in cash to acquire shares of other public firms, amounting to about $2 \%$ of the approximately $\$ 8$ trillion spent on dividends and share repurchases to their own shareholders.
} 


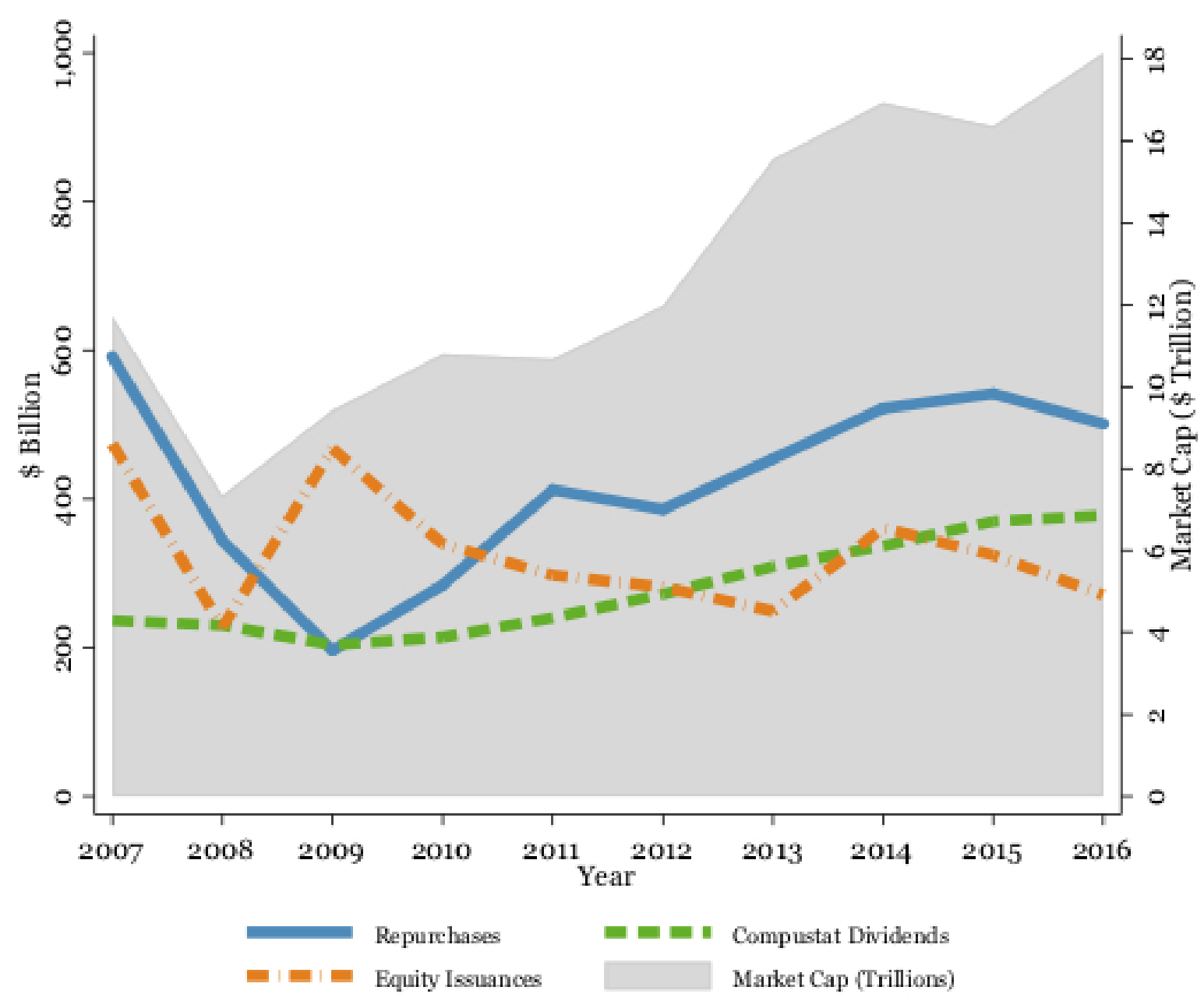

Fig. 3. S\&P 500 Repurchases, Dividends, and Equity Issuances (2007-2016)

The solid line depicts the time series of repurchases among S\&P 500 firms, computed from Compustat as the purchase of common and preferred shares less any decrease in the value of preferred stock. Equity issuances are computed as the sum of CRSP net equity issuances and Compustat repurchases. Market capitalization, the gray background, is computed using calendar-year-end CRSP share and price data. Details of variable construction are presented in Table A1.

equity investors provided the S\&P 500 with more capital than they took out. During 20072016, cumulative net shareholder payouts for the S\&P 500 were approximately $50.41 \%$ of cumulative shareholder payouts. 


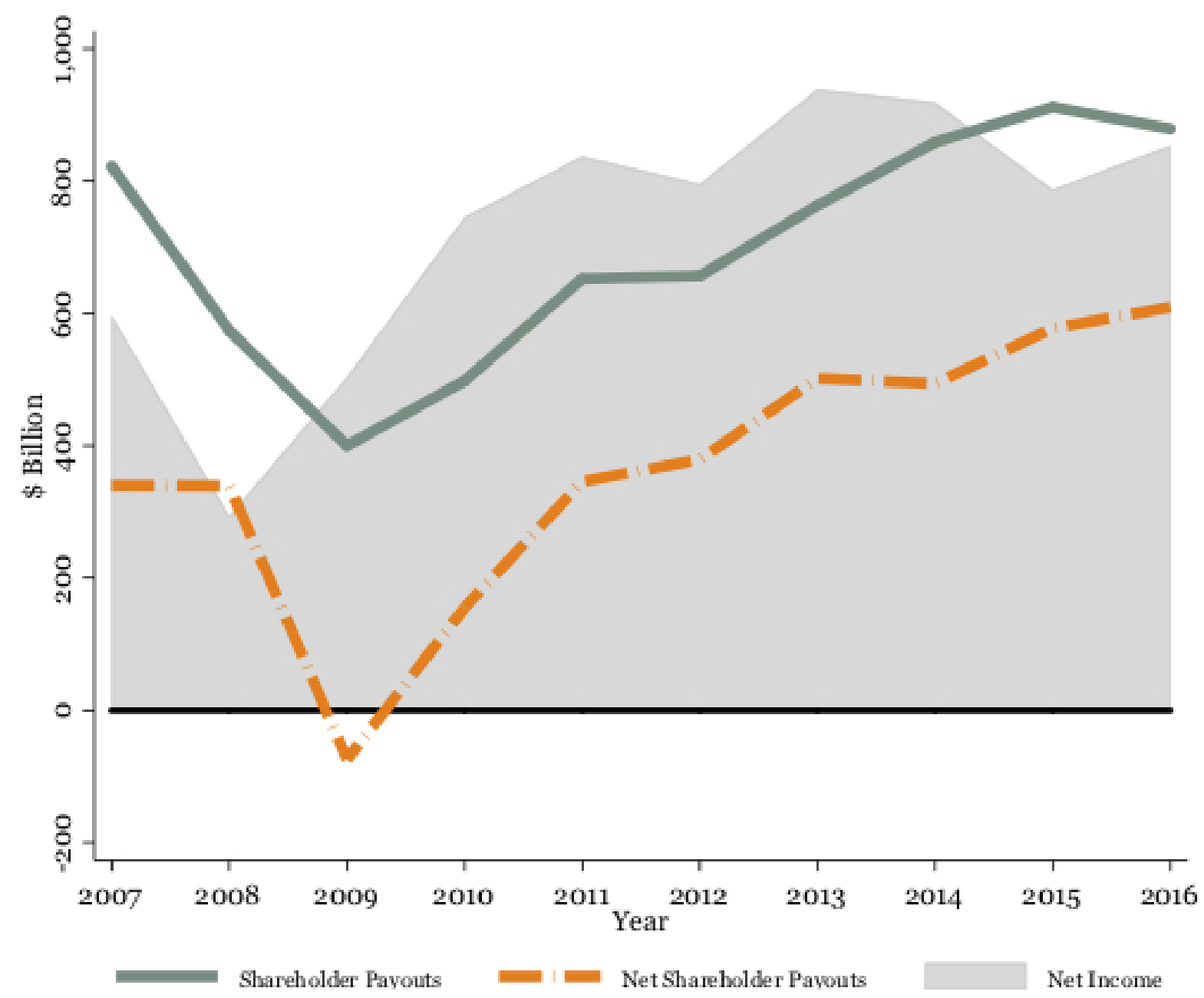

Fig. 4. S\&P 500 Shareholder Payouts and Net Shareholder Payouts (2007-2016) The solid line depicts the time series of annual shareholder payouts among S\&P 500 firms, computed from Compustat as the sum of dividends and repurchases. The dashed line depicts the time series of annual net shareholder payouts, computed using CRSP data as the monthly change in shares outstanding times the average daily share price over the month and summed over the calendar year. Aggregate annual net income, the gray background, is obtained from Compustat. Details of variable construction are presented in Table A1.

\section{Net Shareholder Payouts by All Public Firms}

We have just seen the worse problem with using shareholder payouts (dividends and repurchases) by S\&P 500 firms as evidence of short-termism in the public markets: it ignores 
offsetting equity issuances, both direct and indirect. Yet another problem is using S\&P 500 firms to represent public firms, when they are in fact not representative of public firms in the aggregate. For example, during 2007-2016 the average age of S\&P 500 firms is slightly over 31 years, while the average age of non-S\&P 500 public firms is 12 years. $^{8}$ We would expect older, more mature firms to distribute more capital to shareholders than younger, faster-growing firms. In fact, that is what we find. Non-S\&P 500 firms are actually net importers of equity capital, absorbing much of the net shareholder payouts of S\&P 500 firms. Looking across all public firms, both those in the S\&P 500 and those outside of it, net shareholder payouts to public shareholders are significantly smaller, in absolute terms and as a percentage of net income, than net shareholder payouts from S\&P 500 firms. We first look at non-S\&P 500 firms during 2007-2016, and then integrate these firms with the S\&P 500 firms to provide a complete picture of all public firms and their shareholders.

\section{$4.1 \quad$ Non-S\&P 500 Firms (2007-2016)}

Focusing on public firms outside the S\&P 500, we again find that net shareholder payouts are much lower than shareholder payouts. Indeed, net shareholder payouts are negative in each year, meaning that direct and indirect cash flows from public equity investors to these firms are positive.

Figure 5 displays, for non-S\&P 500 firms during 2007-2016, annual shareholder payouts and annual net shareholder payouts, both against the backdrop of net income. Over the decade, these firms absorbed - directly or indirectly - $\$ 406.81$ billion of equity capital, a substantial portion (about 11\%) of the net shareholder payouts of S\&P 500 firms.

\footnotetext{
${ }^{8}$ We estimate firm age based on the number of years since the first trading date on CRSP.
} 


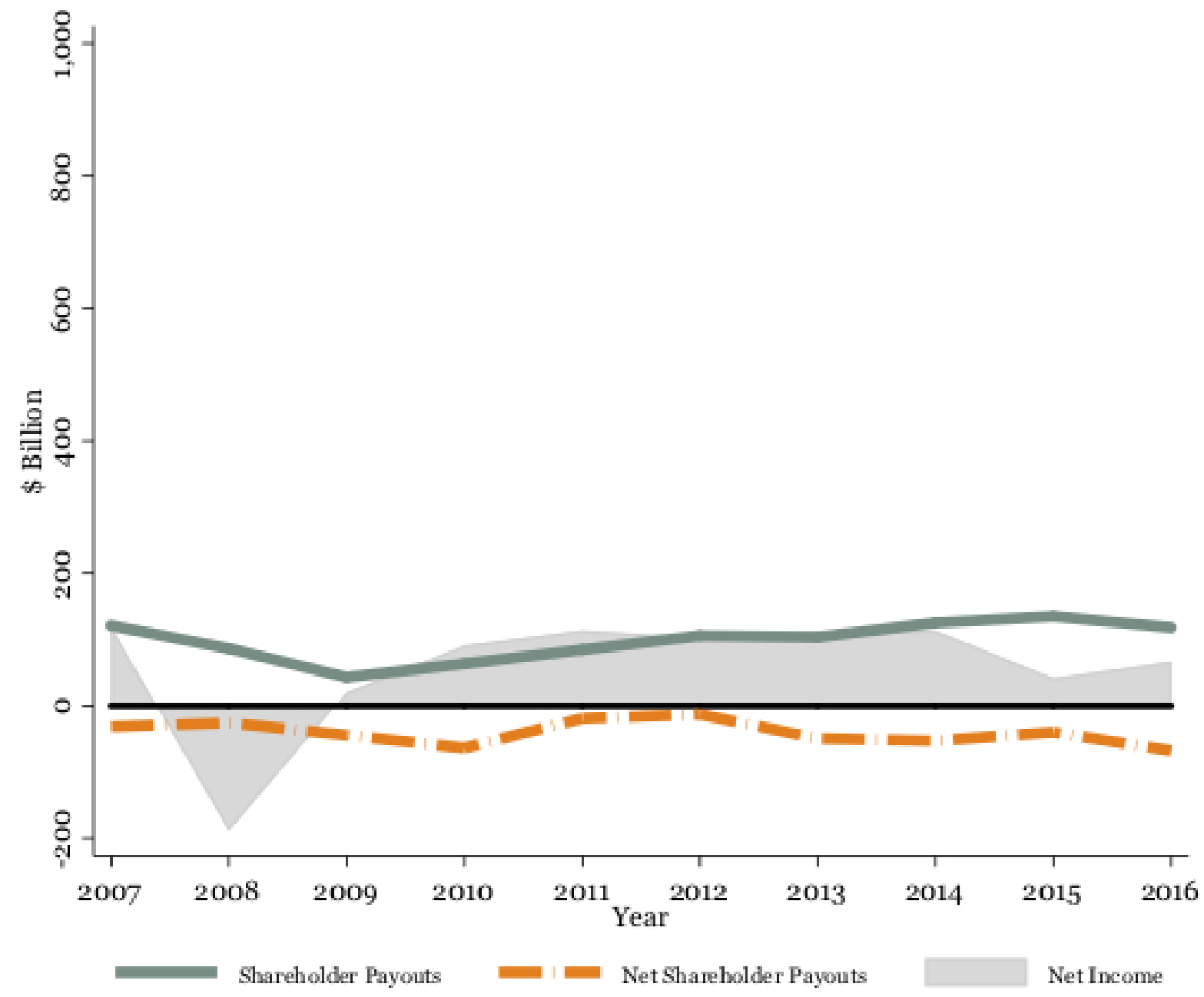

Fig. 5. Non-S\&P 500 Shareholder Payouts and Net Shareholder Payouts (2007-2016) The solid line depicts the time series of annual shareholder payouts among non-S\&P 500 firms, computed from Compustat as the sum of dividends and repurchases. The dashed line depicts the time series of annual net shareholder payouts, computed using CRSP data as the monthly change in shares outstanding times the average daily share price over the month and summed over the calendar year. Aggregate annual net income, the gray background, is obtained from Compustat. Details of variable construction are presented in Table A1. 


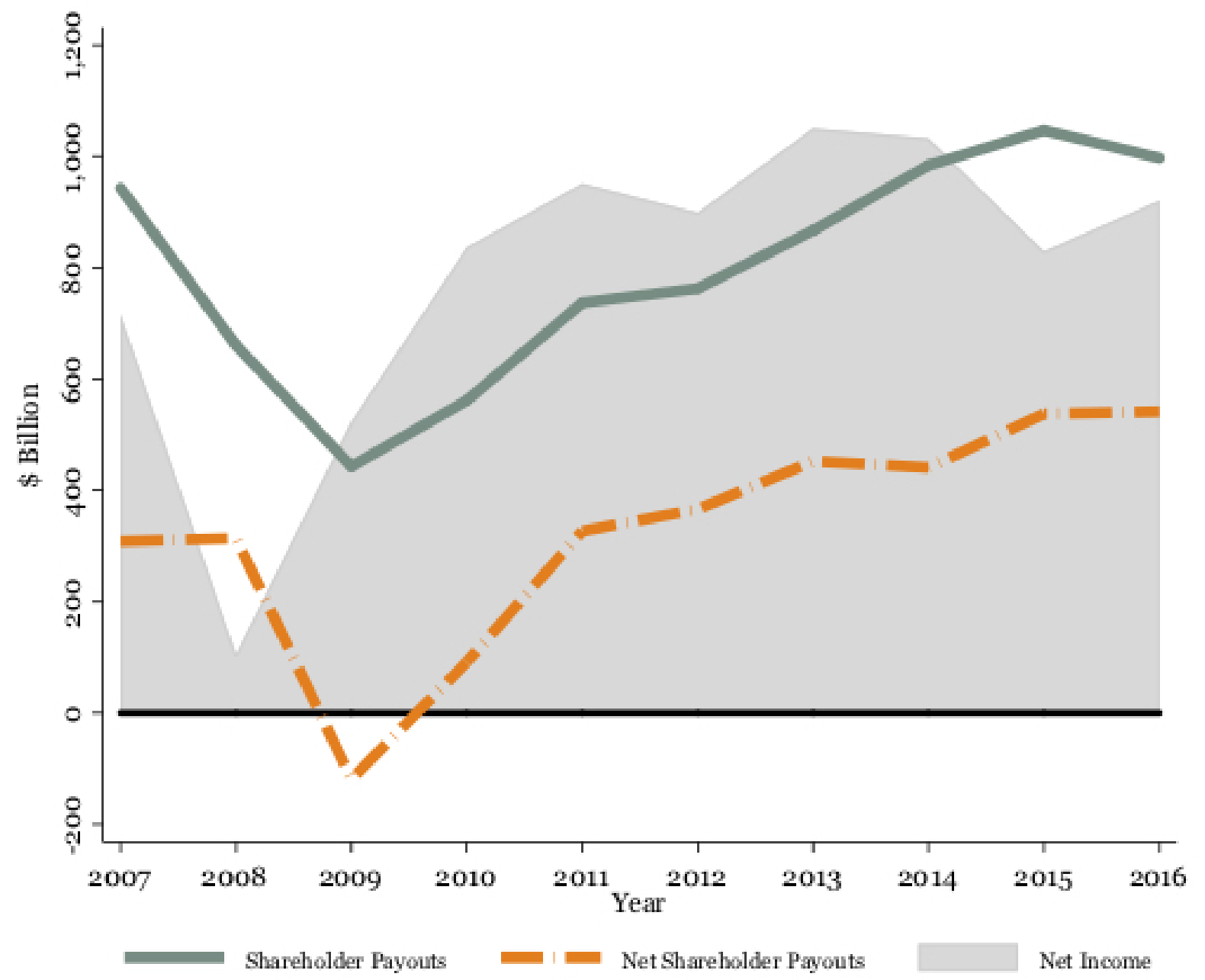

Fig. 6. Public-Firm Shareholder Payouts and Net Shareholder Payouts (2007-2016) The solid line depicts the time series of annual shareholder payouts among all public firms, computed from Compustat as the sum of dividends and repurchases. The dashed line depicts the time series of annual net shareholder payouts, computed using CRSP data as the monthly change in shares outstanding times the average daily share price over the month and summed over the calendar year. Aggregate annual net income, the gray background, is obtained from Compustat. Details of variable construction are presented in Table A1.

\subsection{All Public Firms (2007-2016)}

Integrating the results for S\&P 500 firms and non-S\&P 500 firms during 2007-2016, Figure 6 shows annual shareholder payouts and net shareholder payouts for all public firms. 
Shareholder payouts were about $\$ 8$ trillion. Direct and indirect issuances by public firms totaled approximately $\$ 4.74$ trillion. Thus, net shareholder payouts, approximately $\$ 3.26$ trillion, were a relatively modest fraction of shareholder payouts.

Figure 7 shows cumulative shareholder payouts and cumulative net shareholder payouts against a backdrop of cumulative net income for all public firms during 2007-2016. While cumulative shareholder payouts closely track cumulative net income, cumulative net shareholder payouts are much lower: they total only $41.4 \%$ of cumulative net income.

\section{Examining Net Shareholder Payouts and Investment Capacity}

Having shown that net shareholder payouts from public firms amounted to $41 \%$ of cumulative net income (rather than the oft-cited 90\%+ figures), we proceed to analyze whether, at these levels, net shareholder payouts are likely to drain public firms of the capital necessary needed for investment and innovation. Our analyses below suggest that the answer is decidedly no.

We first examine the ratio of net shareholder payouts to a measure of investment-available income, and show that net shareholder payouts are a relatively small fraction of that measure. We then examine evidence on public firms' investment intensity, and show that there's no evidence of a collapse in R\&D and capital expenditures during 2007-2016. In fact, investment has been rising and ended the period near high levels last seen in the late 1990s. Meanwhile, cash reserves grew substantially, leaving plenty of dry powder available for additional investment. Together, these data make it clear that public firms are not being drained of capital needed for investment. Rather, they are consistent with public firms having more 


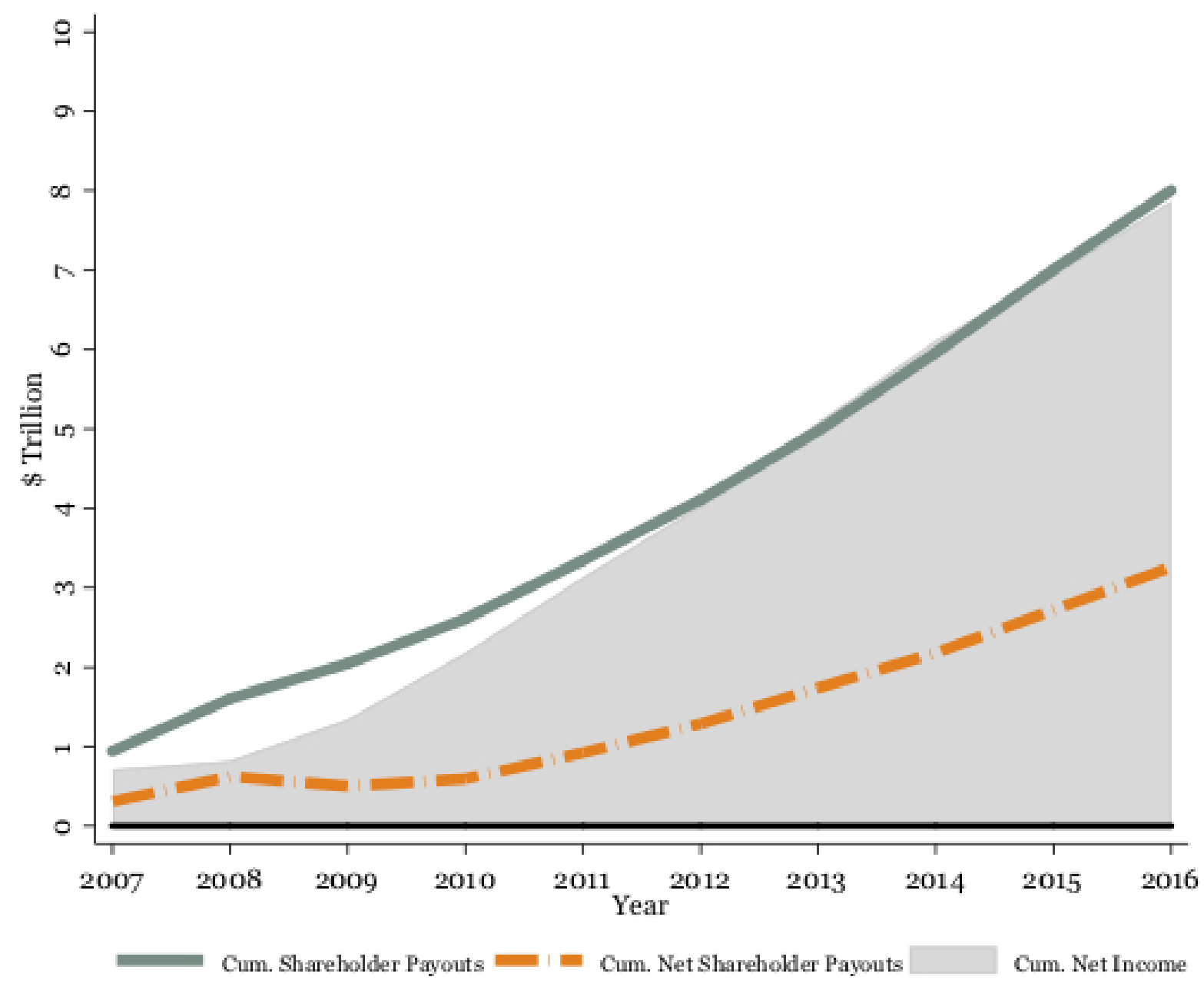

Fig. 7. Public-Firm Cumulative Shareholder Payouts and Net Shareholder Payouts (2007-2016)

The solid line depicts the time series of cumulative shareholder payouts among all public firms, computed from Compustat as the sum of dividends and repurchases. The dashed line depicts the time series of cumulative net shareholder payouts, computed using CRSP data as the monthly change in shares outstanding times the average daily share price over the month and summed over the calendar year. Cumulative aggregate net income, the gray background, is obtained from Compustat. Details of variable construction are presented in Table A1.

capital than they need for the investment opportunities available. ${ }^{9}$

\footnotetext{
${ }^{9}$ To fully trace the sources and uses of capital flows in public firms, one would need to track not only shareholder-firm capital flows but also creditor-firm capital flows. Although such tracing is beyond the scope
} 


\subsection{R\&D-Adjusted Net Income}

Critics of buybacks often compare the magnitude of shareholder payouts to net income, and conclude that public firms are depriving themselves of the resources necessary to grow (Lazonick, 2014). However, not only are shareholder payouts an incorrect measure of shareholder-firm capital flows, but net income is a poor measure of income available for investment: it assumes that the expenses deducted to arrive at net income are entirely unrelated to future-oriented investment. In fact, net income is computed after deducting the substantial expenses associated with $\mathrm{R} \& \mathrm{D}$, which is by definition future-oriented. During 2007-2016, for example, total R\&D expenditures for S\&P 500 companies equalled about $28 \%$ of total net income. Therefore, net income at best measures the amount available for CAPEX and additional R\&D.

A better measure of income available for investment is what we call "R\&D-adjusted net income", which adds a firm's R\&D expenses (net of its effective tax rate) back to its net income. Net shareholder payouts as a percentage of R\&D-adjusted net income appear quite low. During 2007-2016, net shareholder payouts by S\&P 500 firms amounted to only $41.5 \%$ of R\&D-adjusted net income. Even after net shareholder payouts these firms would have had $\$ 5.2$ trillion available for CAPEX, R\&D, and other investment by the end of 2016, even had they started the period with cash balances of zero. Across all public firms, net shareholder payouts were only $33 \%$ of R\&D-adjusted net income, leaving them with $\$ 6.6$ trillion available

of this project, we have developed rough estimates of capital flows between public firms and their creditors. According to our estimates, total marginal debt capital inflows (net borrowing proceeds less after-tax interest payments on incremental net borrowing) for public firms equalled about one-third of net shareholder payouts during the period we study. Because of the coarseness of our estimates, and because debt imposes constraints on the firm's future activities that equity does not, we choose to focus solely on equity capital flows, ignoring debt capital flows. However, it is worth mentioning that debt capital flows are likely to help explain public firms' ability to increase investment and accumulate cash while also engaging in substantial net shareholder payouts. 
for investment by the end of 2016 (again, assuming they started the period with no cash on hand).

Accounting for both equity issuances and R\&D dramatically changes the picture on how much income is available for investment after shareholder payouts. Figure 8 shows that if investment-available income is measured as the difference between net income and shareholder payouts, public firms failed to generate any such income during 2007-2016. In fact, they accumulated a $\$ 136$ billion deficit.

This picture changes dramatically when we take into account equity issuances. Using the difference between net income and net shareholder payouts as a metric for investmentavailable income, Figure 8 shows that public firms accumulated a significant amount of such income during 2007-2016: \$4.6 trillion.

This picture changes yet again when we take into account R\&D expenses. Using the difference between R\&D-adjusted net income and net shareholder payouts as a metric for investment-available income, Figure 8 shows that public firms accumulated $\$ 6.6$ trillion of such income during 2007-2016. These data show quite clearly that shareholder payouts are not starving public companies of the ability to invest, but rather leave firms with substantial amounts of capital for R\&D, capital expenditures, and other uses.

\subsection{Investment Intensity and Cash Balances}

We now consider what public firms did during 2007-2016 with the considerable investment capacity they generated. In fact, during this period public-firm overall investment climbed, reaching record levels in absolute terms and very high levels relative to revenues. Figure 9 plots total investment intensity (the ratio of CAPEX and R\&D to revenues) and R\&D intensity over the 25-year period from 1992 to 2016. While total investment intensity for 

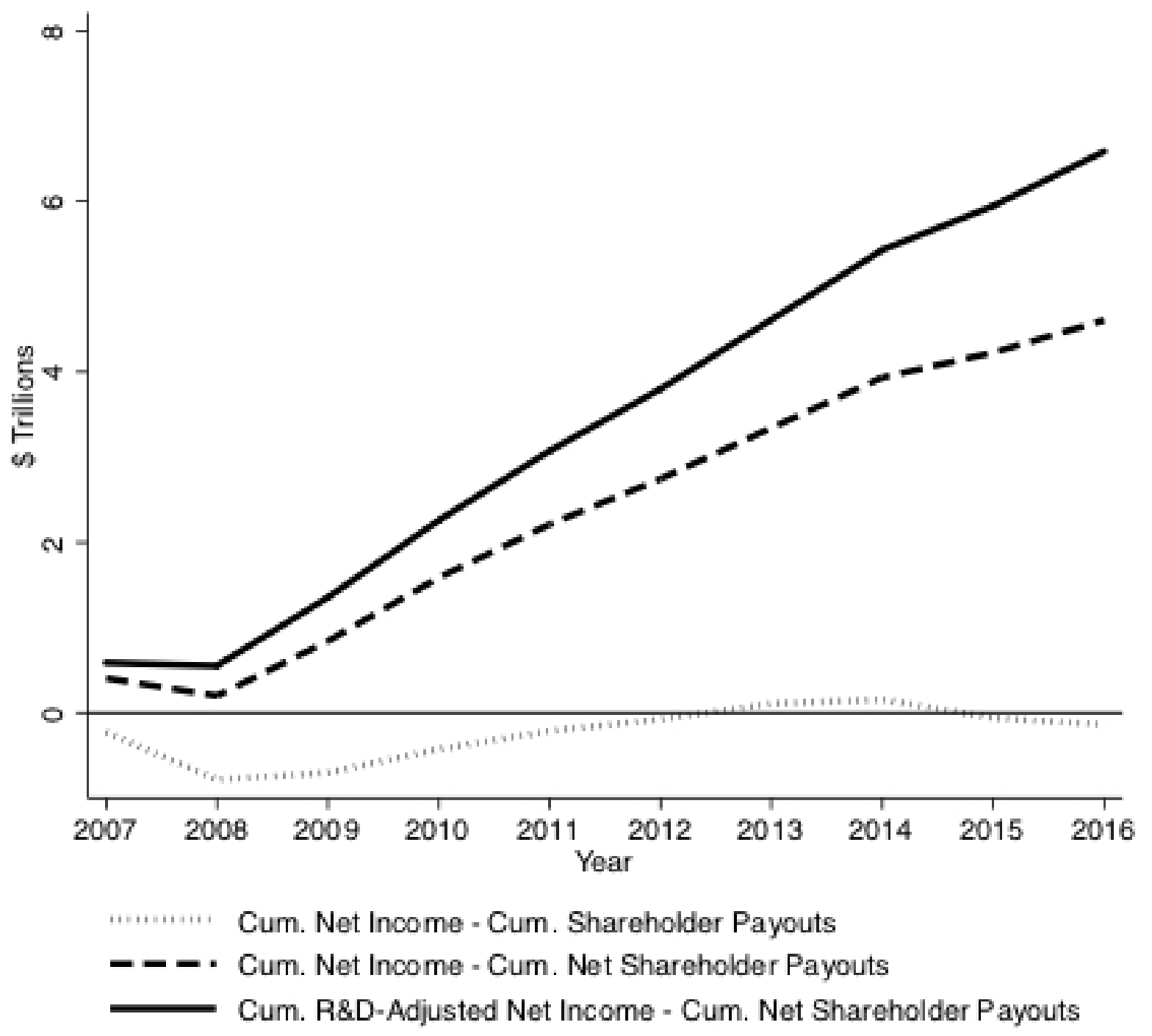

Fig. 8. Public-Firm Cumulative Excess Income Available for Investment (2007-2016) The short-dash line depicts the time series of the difference between public-firm cumulative net income and cumulative shareholder payouts. The long-dash line depicts the difference between public-firm cumulative net income and cumulative net shareholder payouts. Finally, the solid line depicts the time-series of public-firm cumulative $\mathrm{R} \& \mathrm{D}$-adjusted net income and cumulative net shareholder payouts, where R\&D-adjusted net income is net income plus R\&D expense (net of effective tax rate). Details of variable construction are presented in Table A1. 


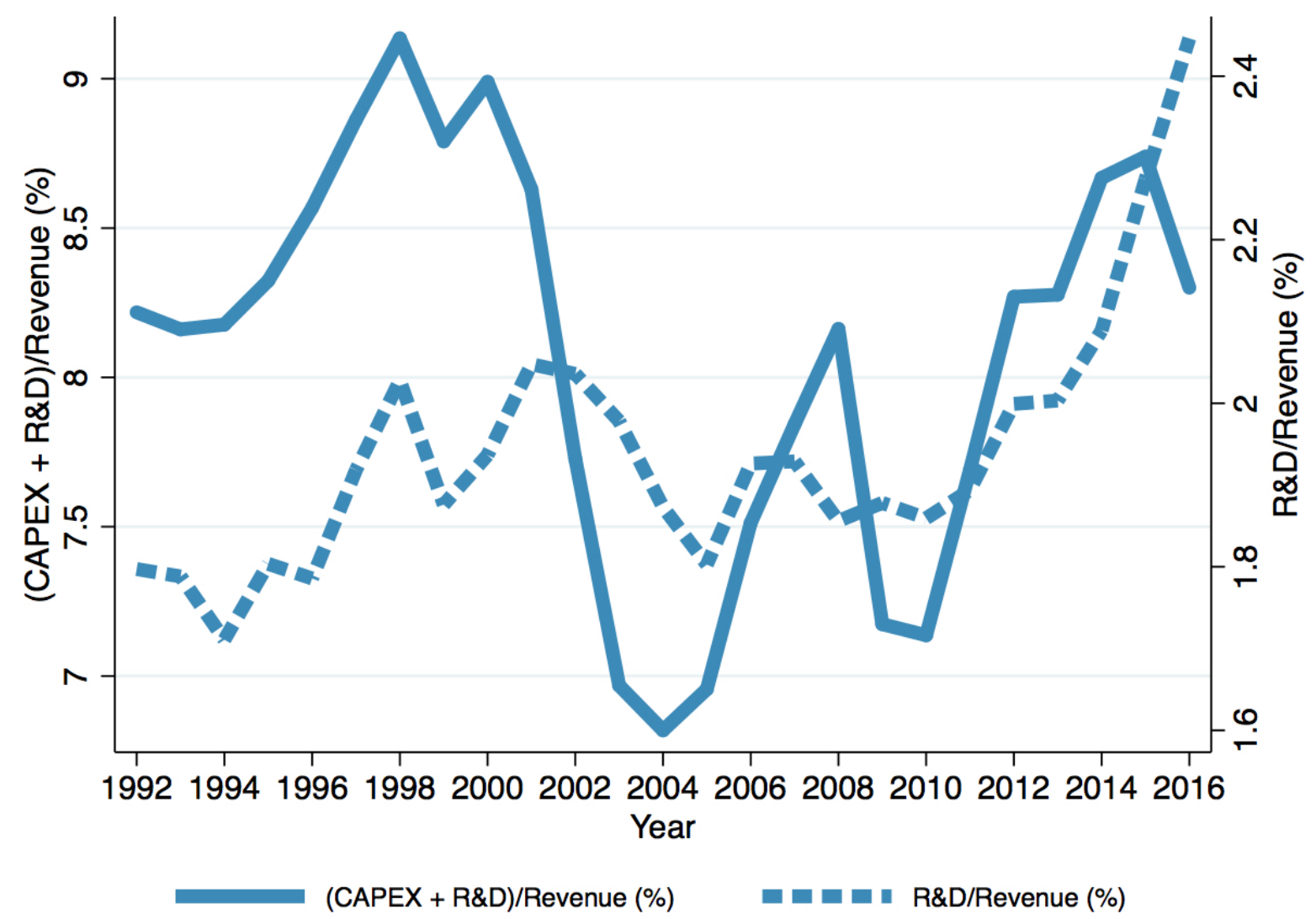

Fig. 9. Public-Firm Investment Intensity (1992-2016)

The solid line depicts the time series of annual total public-firm investments, sum of capital expenditures (CAPEX) and research and development expenses (R\&D), divided by annual total public-firm revenues. The dash line depicts the time series of public-firm annual total $R \& D$ expenses divided by annual total public-firm revenues. CAPEX, R\&D, and revenues data are all obtained from Compustat. Details of variable construction are presented in Table A1.

public firms firms is volatile on a year-to-year basis, it generally rose during 2007-2016, and is now near high levels not seen since the late 1990s boom. By the end of the period, R\&D intensity was at a historical high.

One might argue investment intensity would have been even higher had firms not distributed so much capital to shareholders. Although we cannot observe this counterfactual, we note that corporate cash stockpiles were huge and growing during 2007-2016. Figure 10 


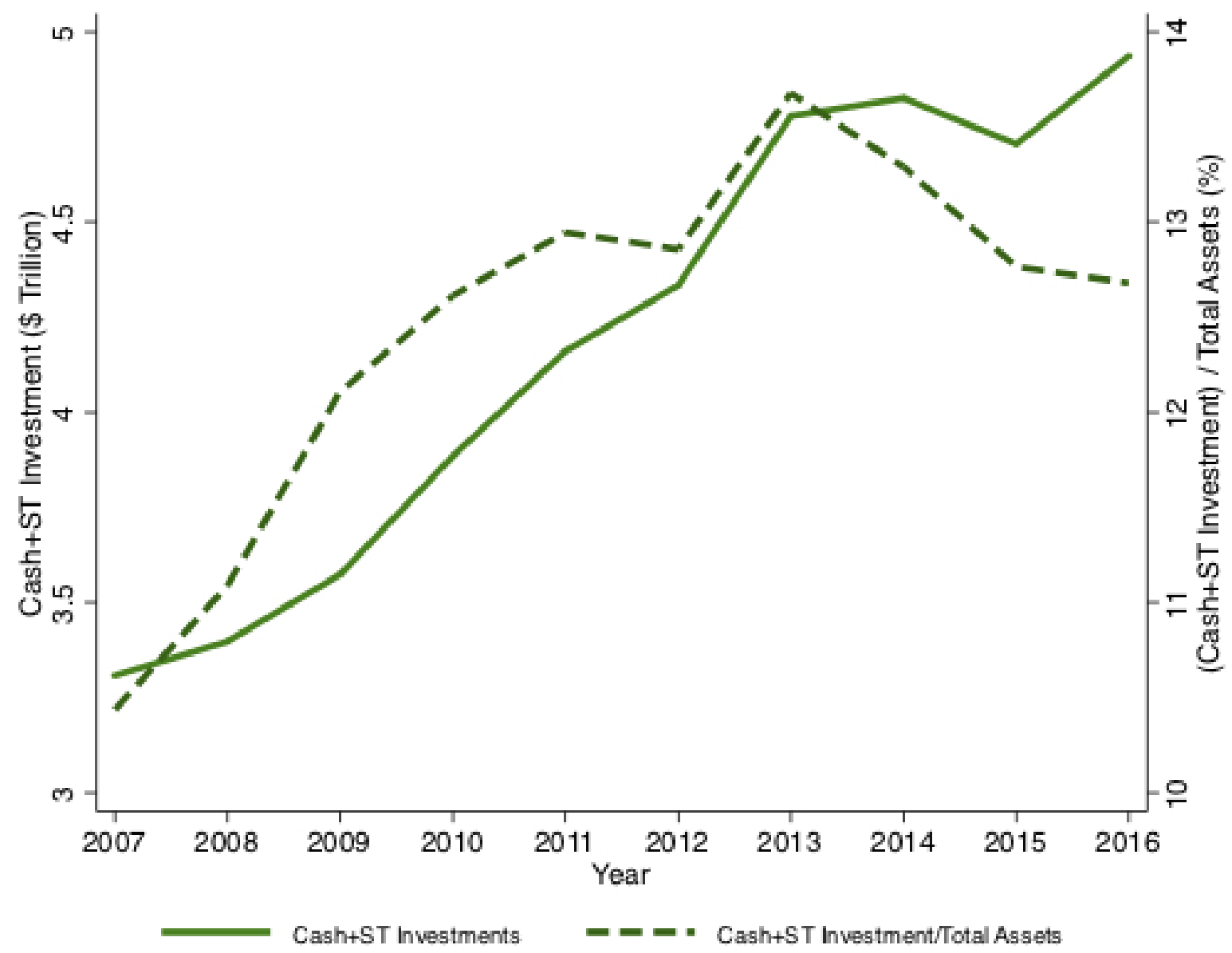

Fig. 10. Public-Firm Cash Balances (2007-2016)

Cash and short-term investments (Compustat field che) and total assets (Compustat field at) are obtained from Compustat. The dashed time series reports the ratio of the public-firm aggregate annual cash and short-term investment to aggregate annual total assets.

reports aggregate cash (and cash-equivalent short-term investments) on public firms' balance sheets during 2007-2016. In 2007, public firms held $\$ 3.3$ trillion in cash. By 2016, this stash had grown by nearly $50 \%$, to $\$ 4.9$ trillion.

To be sure, some of this cash was held abroad and would have been taxed if repatriated for investment in the United States. But even if we were to assume that all of the public 
firms' available cash were held abroad and would still have been taxed on repatriation at the highest possible rate in 2016 (35\%), that would have left approximately $\$ 3.2$ trillion available to public firms in 2016 for internal investment. ${ }^{10}$

These data indicate that public firms in aggregate had considerable domestic cash reserves during 2007-2016, reserves that did not dry up as a result of large shareholder payouts but rather increased despite them. Thus, it seems unlikely that investment intensity in public firms was restrained because firms lacked cash. Rather it appears that there were not enough investment opportunities to absorb all of the cash left after firms engaged in share repurchases and dividends.

\section{Looking Beyond the Public-Firm Data}

We close by offering two reasons why, regardless of the actual amounts of net shareholder payouts, investment, and cash buildup by public firms, one could not necessarily conclude that that public firms and the economy as a whole are being harmed by excessive capital flows to public investors.

\subsection{Public Firms Can Always Issue More Equity}

Even if a firm's net shareholder payouts were very high relative to R\&D-adjusted net income, the firm would not necessarily lack the capacity to invest and innovate, as it is likely to be able to issue more stock. The amount of equity issued by any given public firm in any given year does not represent a cap; the firm could generally have issued even

\footnotetext{
${ }^{10}$ In fact, much of the cash during this period was held domestically, according to domestic-cash data generously provided to us by Siko Sikochi on about 1,100 public firms during 2012-2016. These data also show that these firms' domestic cash balances grew during 2012-2016, the last five years of the 2007-2016 period that we study.
} 
more stock to raise cash, acquire assets, or pay employees. Thus, if that firm has a valuable investment opportunity, but little cash, the firm can often use equity financing to exploit the opportunity.

To be sure, there can be constraints on the ability or willingness of firms to issue additional shares. In the rare case where a firm has already reached the share-authorization ceiling under its charter, the board would need shareholder approval to raise the ceiling before the firm could issue more shares. But such approval should be forthcoming when shareholders can be convinced that the investment facilitated by the equity issuance would benefit them.

A more common constraint is that, if the firm's stock is underpriced, executives serving current shareholders will not wish to issue additional stock unless the investment opportunity is particularly attractive. In fact, when the stock is sufficiently underpriced, executives serving long-term shareholders may under-invest in valuable opportunities inside the firm to free up funds to buy discounted shares (Fried, 2015). And executives may also have compensation-related reasons for disfavoring a large increase in the share count. But if the opportunity is attractive enough, both current shareholders and executives can benefit from the firm issuing more shares, even if the stock is currently underpriced.

\subsection{Net Shareholder Payouts by Public Firms Can Flow to Private Firms}

The concern about the volume of shareholder payouts appears to be based, in part, on an implicit assumption that there is no economic benefit to putting cash in the hands of public shareholders. But net shareholder payouts from public companies do not all disappear down the economic drain. Just as much of the net shareholder payouts from S\&P 500 firms flow to smaller public firms outside the S\&P 500, net shareholder payouts from public companies 
in the aggregate could be invested in firms raising capital through an IPO, or in non-public businesses backed by private equity or venture capital.

While tracing capital flows into private companies is difficult, we do know that capital circulates in the economy and that venture capital and private equity funds are now raising more than $\$ 200$ billion per year - a substantial fraction of the net shareholder payouts generated by all public firms - for investment in private firms (Prequin, 2018). These firms are vital to the U.S. economy. They account for more than $50 \%$ of non-residential fixed investment, employ almost $70 \%$ of U.S. workers, and generate nearly half of business profit (Asker et al., 2015). Indeed, much of the critical innovation in our economy-including breakthroughs in pharmaceuticals and information technology - takes place in small private firms (Roe, 2013). Consider hydraulic fracturing and horizontal drilling ("fracking"), which has been described as "the largest single opportunity to change America's competitiveness and economic trajectory, as well as our geopolitical standing" (Porter, Gee, and Pope, 2015). Among other things, fracking has turned the U.S. into an energy superpower, generated 2.7 million high-paying new jobs, provided a much needed boost to the manufacturing sector, and revived struggling regions of the country (Porter et al., 2015). Fracking was not developed by large publicly-traded energy firms such as ExxonMobil, but rather by entrepreneurs and small firms financed with private equity capital (Touryalai, 2012).

In short, even if net shareholder payouts by public firms were high relative to investmentavailable income, one could not conclude that these payouts were undermining investment and innovation in the U.S. without taking into account their effect on investment and innovation in private firms. 


\section{Conclusion}

During 2007-2016, shareholders of S\&P 500 firms received $\$ 7$ trillion in shareholder payouts (dividends and repurchases). These payouts represented over $96 \%$ of the firms' net income during this period. Such shareholder-payout figures are widely relied on by certain academics, corporate lawyers, asset managers, and politicians as evidence that "short-termism" and "quarterly capitalism" are impairing public firms' ability to invest and innovate. We

have shown, however, that net shareholder payouts by public firms are only approximately $41 \%$ of net income, and an even lower percentage of income available for investment. Our findings can explain why investment by public firms reached record levels during this period, even as these firms accumulated trillions of dollars in cash.

In short, the volume of share repurchases and dividends by the largest public firms is highly unlikely to indicate that short-termism, or some other factor, is causing public firms to distribute too much cash to shareholders. Those arguing that short-termism is harming public companies will have to look elsewhere to find support for their claim. 


\section{References}

Almeida, H., V. Fos, and M. Kronlund (2016). The Real Effects Of Share Repurchases. Journal of Financial Economics 119(1), 168-185.

Asker, J., J. Farre-Mensa, and A. Ljungqvist (2015). Corporate Investment and Stock Market Listing: A Puzzle? Review of Financial Studies 28(2), 342-390.

Aspen Institute (2009). Overcoming Short-termism: A Call for a More Responsible Approach to Investment and Business Management. https://www.aspeninstitute.org/publications/overcoming-short-termism-call-moreresponsible-approach-investment-business-management/.

Baker, M. and J. Wurgler (2002). Market Timing and Capital Structure. Journal of Finance $57(1), 1-32$.

Bebchuk, L., A. Brav, and W. Jiang (2015). The Long-Term Effects of Hedge Fund Activism. Columbia Law Review 115(5), 1085-1156.

Bebchuk, L. and R. Jackson (2012). The Law and Economics of Blockholder Disclosure. Harvard Business Law Review 2, 39.

Bebchuk, L. a. (2013). The Myth that Insulating Boards Serves Longterm Value. Columbia Law Review 113(10), 1637-1694.

Bens, D. A., V. Nagar, D. J. Skinner, and M. H. F. Wong (2003). Employee Stock Options, EPS Dilution, and Stock Repurchases. Journal of Accounting and Economics 36 (1), 51-90.

Biden, J. (2016, 9). How Short-Termism Saps the Economy. Wall Street Journal, September 27, http://www.wsj.com/articles/how-short-termism-saps-the-economy-1475018087. 
Boudoukh, J., R. Michaely, M. Richardson, and M. R. Roberts (2007). On the Importance of Measuring Payout Yield: Implications for Empirical Asset Pricing. Journal of Finance 62(2), 877-915.

Bushee, B. J. (1998). The Influence of Institutional Investors on Myopic R\&D Investment Behavior. The Accounting Review 73(3), 305-333.

Coffee, J. C. and D. Palia (2015). The Wolf at the Door: The Impact of Hedge Fund Activism on Corporate Governance. Columbia Law School Working Paper No. 521.

Cremers, K. J. M., L. P. Litov, and S. M. Sepe (2017). Staggered Boards and Long-Term Firm Value, Revisited. Journal of Financial Economics (Forthcoming).

Cremers, M., E. Giambona, S. M. Sepe, and Y. Wang (2016). Hedge Fund Activism and Long-Term Firm Value. Working Paper.

Dichev, I. D., J. R. Graham, C. R. Harvey, and S. Rajgopal (2013). Earnings Quality: Evidence from the Field. Journal of Accounting and Economics 56(2), 1-33.

Easterbrook, F. H. (1984). American Economic Association The Origin of Predictable Behavior Author ( s ): Ronald A. Heiner Source: The American Economic Review, Vol . 73, No .4 ( Sep ., 1983 ), pp . 560-595 Published by : American Economic Association Stable URL : https://www. American Economic Review 73(4), 650-659.

Eckbo, B. E., T. Makaew, and K. Thorburn (2016). Are Stock-Financed Takeovers Opportunistic? ECGI - Finance Working Paper No. 393/2013.

Fama, E. F. and K. R. French (2001). Disappearing Dividends: Changing Firm Characteristics Or Lower Propensity To Pay? Journal of Financial economics 60(1), 3-43. 
Fama, E. F. and K. R. French (2005). Financing Decisions: Who Issues Stock? Journal of Financial Economics 76(3), 549-582.

Farre-Mensa, J., R. Michaely, and M. Schmalz (2018). Financing Payouts. Ross School of Business Paper No. 1263.

Fink, L. (2015). Letter To CEOs. March 31, http://www.shareholderforum.com/access/Library /20150331_BlackRock.pdf.

Floyd, E., N. Li, and D. J. Skinner (2015). Payout Policy Through The Financial Crisis: The Growth Of Repurchases And The Resilience Of Dividends. Journal of Financial Economics 118(2), 299-316.

Frank, M. Z. and V. K. Goyal (2003). Testing the Pecking Order Theory of Capital Structure, Volume 67.

Fried, J. M. (2015). The Uneasy Case for Favoring Long-Term Shareholders. Yale Law Journal 124, 1554-1628.

Gilson, R. J. and J. N. Gordon (2013). The Agency Costs of Agency Capitalism: Activist Investors and the Revaluation of Governance Rights. Columbia Law Review 113(4), 863927.

Graham, J. R., C. R. Harvey, and S. Rajgopal (2006). Value Destruction and Financial Reporting Decisions. Financial Analysts Journal 62(6), 27-39.

Grullon, G. and R. Michaely (2004). The Information Content of Share Repurchase Programs. The Journal of Finance LIX(2), 651-680. 
Gutiérrez, G. and T. Philippon (2017). Investmentless Growth: An Empirical Investigation. Brookings Papers on Economic Activity (Fall), 89-169.

Hribar, P., N. T. Jenkins, and W. B. Johnson (2006). Stock repurchases as an earnings management device. Journal of Accounting and Economics 41,3-27.

Jensen, M. C. (1986). Agency Costs of Free Cash Flow, Corporate Finance, and Takeovers. American Economic Review 76(2), 323-329.

Kahan, M. and E. Rock (2007). Hedge Funds in Corporate Governance and Corporate Control. University of Pennsylvania Law Review 155(5), 1021-1093.

Kahle, K. (2002). When a Buyback Isn’t a Buyback: Open Market Repurchases and Employee Options. Journal of Financial Economics 63(2), 235-261.

Kahle, K. and R. M. Stulz (2017). Is the US Public Corporation in Trouble? Journal of Economic Perspectives 31(3), 67-88.

Kaplan, S. N. (2017). Are U . S . Companies Too Short-Term Oriented ? Some Thoughts. Working Paper (February).

Lazonick, W. (2014). Profits Without Prosperity. Harvard Business Review 92(9), 46-55.

Lee, D., H.-H. Shin, and R. Stulz (2016). Why Does Capital No Longer Flow More to the Industries with the Best Growth Opportunities?

Lemmon, M. and J. Zender (2003). Debt Capacity and Tests of Capital Structure Theories. 45(5), 1161-1187. 
Lipton, M. (2015). Some Thoughts For Boards Of Directors In 2016. December 9, Harvard Law School Forum on Corporate Governance and Financial Regulation, https://corpgov.law.harvard.edu/2015/12/09/some-thoughts-for-boards-of-directorsin-2016/.

Office of Elizabeth Warren (2018). Warren Introduces Accountable Capitalism Act: Comprehensive Legislation to Eliminate Skewed Market Incentives and Return to the Era When American Corporations and American Workers Did Well Together [Press Release]. Retrieved from https://www.warren.senate.gov/newsroom/press-releases/warren-introducesaccountable-capitalism-act.

Porter, M., D. Gee, and G. Pope (2015). America's Unconventional Energy Opportunity. Technical report, Harvard Business School.

Prequin (2018). Private Equity Fundraising In 2017: A Global Story.

Roe, M. J. (2013). Corporate Short-Termism in the Boardroom and in the Courtroom. The Business Lawyer 68, 977-1006.

Roe, M. J. (2018). Stock Market Short-Termism's Impact. Working Paper.

Simkovic, M. (2009). The Effect of Mandatory Disclosure On Open-Market Repurchases. Berkeley Business Law Journal 6(1), 96-130.

Skinner, D. J. (2008). The Evolving Relation Between Earnings, Dividends, And Stock Repurchases. Journal of Financial Economics 87(3), 582-609.

Stein, J. C. (1989). Efficient capital markets, inefficient firms: a model of myopic corporate behavior. The Quarterly Journal of Economics November, 655-669. 
Strine, L. E. (2010). One Fundamental Corporate Governance Question We Face: Can Corporations Be Managed For The Long Term Unless Their Powerful Electorates also Act and Think Long Term. Business Lawyer 66(1), 1-26.

Touryalai, H. (2012). Guess Who's Fueling the Fracking Boom? October 3, Forbes, http://www.forbes.com/sites/halahtouryalai/2012/10/03/guess-whos-fueling-thefracking-boom/.

Welch, I. and A. Goyal (2008). A Comprehensive Look at The Empirical Performance of Equity Premium Prediction. Review of Financial Studies 21(4), 1455-1508. 
Table A1. Description of Variables

\begin{tabular}{ll}
\hline \hline Variable & Description \\
\hline Repurchases & Following Boudoukh et al. (2007), we estimate re- \\
& purchases as the purchase of common and pre- \\
& ferred shares (Compustat item prstkc) less any de- \\
& crease in the value of preferred stock (Compustat \\
& item pstkrv).
\end{tabular}

Compustat Dividends

CRSP Dividends

Net Equity Issuances

Equity issuances

Net Income

Shareholder Payouts

Net Shareholder Payouts
Dividends to common/ordinary shares (Compustat item $d v c)$.

We define dividends to common shares for firm $i$ in month $t$ from the CRSP monthly data as ret $_{t}-$ ret $\left._{t}\right) \times\left(\right.$ shrout $\left._{t} \times c f a c s h r_{t}\right) \times\left(\right.$ prc $\left._{t-1} / c f a c p r_{t-1}\right)$, where ret is the holding period return, ret $x$ is the return excluding dividends, where shrout is the number of shares outstanding at the end of the month, cfacshr is the cumulative factor to adjust shares, cfacpr is the cumulative factor to adjust price, and $\operatorname{prc}$ is the month-end share price.

We estimate net equity issuances using CRSP as the change in shares between two months multiplied by the average price of the current month: $\left[\left(\right.\right.$ shrout $_{t} \times c$ facshr $\left._{t}\right)-\left(\right.$ shrout $\left.\left._{t-1} \times c f a c s h r_{t-1}\right)\right] \times$ $\left[\right.$ mean $\left(\operatorname{prc}_{t}\right) /$ cfacpr $\left._{t}\right]$

We estimate total equity issuances by summing net equity issuances (computed using CRSP data) and repurchases (computed using Compustat)

Fiscal year-end net income (Compustat item $n i$ ).

Shareholder payouts are the sum of repurchases and dividends, both computed from Compustat.

Net shareholder payouts are estimated by the sum of dividends less net equity issuances, both computed using CRSP. 